\title{
Analisis Nilai Religiusitas sebagai Penguatan Toleransi di Desa Pancasila Lamongan Jawa Timur
}

\author{
Fitri Alfariz ${ }^{1}$ \\ 1Jurusan IImu Filsafat, Universitas Gadjah Mada, Yogyakarta, Indonesia \\ E-mail: Alfariz@ugm.ac.id
}

\begin{abstract}
Abstrak
Desa Balun, Kecamatan Turi, Lamongan, Jawa Timur menjadi salah satu desa di Indonesia yang dijuluki Desa Pancasila. Desa Pancasila merupakan nama yang diberikan kepada suatu desa yang menunjukkan keharmonisan nilai-nilai Pancasila. Desa yang berpenduduk lebih dari 4000 orang ini memiliki sikap-sikap toleransi dan kerukunan antar umat beragama yang sangat kuat. Penelitian ini bertujuan untuk mengungkap dan menjelaskan nilai toleransi di dalam Desa Balun (Desa Pancasila) agar dipahami oleh masyarakat luas. Penelitian ini juga sebagai implementasi Pancasila karena desa yang menjaga kearifan lokal dan toleransi merupakan bentuk nyata dari membumikan Pancasila. Prosedur Penelitian dilakukan melalui studi pustaka, studi lapangan dan wawancara mendalam. Penelitian ini merupakan penelitian pendahuluan sebagai grand design Penelitian tentang Desa Pancasila yang ada di Indonesia. Klasifikasi, analisis, dan interpretasi data dilakukan untuk memperoleh pandangan yang berimbang, objektif dan mendalam. Hasil penelitian menunjukkan bahwa nilai religiusitas sangat berpengaruh terhadap penguatan toleransi yang ada di Desa Balun (Desa Pancasila). Toleransi antarumat beragama dibangun dengan basis nilai instrumental (pedoman berperilaku), nilai sosial (pengikat masyarakat yang berbeda agama) dan komitmen moral (sikap alami dalam keseharian) masyarakat Desa Balun (Desa Pancasila).
\end{abstract}

Kata Kunci: desa Pancasila; religius, toleransi.

\begin{abstract}
Balun Village, Turi Subdistrict, Lamongan, East Java is one of the villages in Indonesia which is nicknamed Desa Pancasila. Desa Pancasila is the name given to a village that shows the harmony of Pancasila values. The village, which has a population of more than 4,000 people, has very strong attitudes of tolerance and inter-religious harmony. This study aims to reveal and explain the value of tolerance in Balun Village (Desa Pancasila) so that it is understood by the wider community. This research is also an implementation of Pancasila because villages that maintain local wisdom and tolerance are a real form of grounding Pancasila. Research procedures were carried out through literature studies, field studies and in-depth interviews. This research is a preliminary research as a grand design research on Desa Pancasila in Indonesia. Data classification, analysis and interpretation are carried out to obtain a balanced, objective and in-depth view. The results showed that the value of religiosity is very influential on the strengthening of tolerance in Balun Village (Desa Pancasila). Tolerance between religious believers is built on the basis of instrumental values (behavior guidelines), social values (binders for people of different religions) and moral commitment (natural attitudes in everyday life) of the Balun Village community (Desa Pancasila).
\end{abstract}

Keywords: desa Pancasila; religious; tolerance

\section{Pendahuluan}

Negara Indonesia secara teori adalah negara yang memiliki ideologi Pancasila, tetapi persoalan implementasi Pancasila di negara ini masih perlu banyak perhatian. Multikulturalisme yang merupakan ketetapan bagi bangsa Indonesia menjadi tantangan dengan hadirnya beberapa oknum yang menggelorakan intoleransi dan radikalisasi. Memang tidak mudah merawat negara yang berisi dari lebih dari dua ratus lima puluh juta jiwa penduduk ini.

Badan Pembinaan Ideologi Pancasila (BPIP) pada November tahun ini telah memberikan penghargaan kepada Pemerintah Kabupaten Blitar dan empat desa yang ada di dalamnya berkaitan dengan nilai-nilai Pancasila yang berkembang di area tersebut. Lembaga Penggerak Pancasila merupakan penghargaan yang diraih Kabupaten Blitar sebagai daerah yang menjunjung tinggi nilai- 
nilai Pancasila sebagai bagian dari laku hidup (Maarif, 2020). Tidak hanya di Blitar saja, pemerintah sedang gencar untuk mengapresiasi nilai-nilai Pancasila yang digalakkan oleh masyarakat berbasis kearifan lokal. Salah satunya terdapat di Aceh Tenggara yang diresmikan pula Oktober ini oleh MPR RI yakni Desa Wisata Pancasila. Latar belakang dari pemberian gelar tersebut juga tidak jauh dari elevasi nilai-nilai Pancasila. Usaha pemuda desa setempat untuk membuat inisiasi baru dalam mengubah hutan menjadi tempat wisata alam dengan semangat gotong royong demi memajukan perekonomian masyarakat merupakan kerja keras yang patut diapresiasi (Masrizal, 2020).

Namun, sebelum adanya penghargaan terhadap kedua kabupaten tersebut, ada satu kabupaten di Jawa Timur yang memiliki julukan sebagai Desa Pancasila karena keunikan nilai kearifan lokal terutama sistem religi di dalamnya, yakni Desa Balun, Kecamatan Turi, Kabupaten Lamongan (medcom.id, 2020). Ciri khas dari Desa Balun yang menarik adalah konsep toleransi antar agama yang ada di Desa Balun. Bedo raginyo, sing penting rukun bukan hanya slogan tetapi merupakan alam pikiran masyarakat Desa Balun, aktivitas dan sikap masyarakat desa yang saling memberi penghormatan antar agama sangat kuat. Oleh karena itu, Desa Balun diresmikan pada April 2019 sebagai destinasi wisata religi setelah sebelumnya mendapatkan gelar Desa Pancasila (Sudjarwo, 2019). Tidak heran jika Desa Balun juga dianggap menjadi Desa Pancasila dan Desa Pariwisata Religi terlengkap di Kabupaten Lamongan (surabaya.tribunnews.com, 2019).

Penelitian ini akan mencoba melihat dan menarasikan Pancasila sebagai dasar negara Indonesia, nilai-nilainya benar-benar ada di dalam kehidupan masyarakat desa Balun. Pancasila menjadi suatu keniscayaan yang digagas oleh founding father kita sebagai dasar dan filsafat negara. Pancasila dijadikan sebagai alat pemersatu bangsa yang beraneka ragam jumlah penduduknya. Desa Balun, Kecamatan Turi Kabupaten Lamongan menjadi salah satu desa yang menarik untuk dijadikan objek penelitian karena terkenal dengan desa Pancasila. Desa adalah miniatur Indonesia dan Desa Balun merupakan miniatur Indonesia yang memiliki kearifan lokal dan nilai-nilai Pancasila. Peneliti merasa tertantang dan tertarik untuk melakukan penelitian karena penelitian tentang Desa Pancasila masih cukup minim misalnya penelitian tentang tradisi Islam dalam Pernikahan di Desa Balun (Khoiroh, 2017), penelitian lain fokus pada Wisata Religi di Desa Balun (Ismail, 2019), ada juga penelitian yang ada di Desa Balun tetapi fokus kajiannya pada komunikasi tokoh agama dalam upaya menepis Sara (Pirandita, 2020). Peneliti mencoba memberikan analisis yang sedikit berbeda yaitu tentang kajian kearifan lokal dan analisis nilai religiusitas di Desa Balun (Desa Pancasila).

\section{Metode}

Penelitian ini merupakan penelitian lapangan dan penelitian Pustaka yang focus kajiannya adalah Desa Balun (Desa Pancasila) yang dikaji dari perspektif kearifan local dan aspek nilai religiusitas. Objek penelitian dibagi menjadi dua model, yakni objek material dan objek formal. Objek material penelitian adalah masyarakat desa Balun atau Desa Pancasila yang ada di kabupaten Lamongan Jawa Timur. Objek formal penelitian adalah konsep kearifan lokal yang disusun pengertiannya melalui studi kepustakaan.

Teknik pengumpulan data dengan melakukan investigasi studi pustaka, studi lapangan, wawancara mendalam kepada responden. Data diambil untuk memperkuat informasi awal pada objek formal dan objek material penelitian. Penelitian ini merupakan penelitian pendahuluan. Kriteria perekrutan data pada objek penelitian dilakukan berdasarkan wawancara. Setelah itu melakukan klasifikasi data, yakni memilah dan memilih data primer dan sekunder untuk memperoleh data yang representif dan bermutu tinggi. Berikutnya Analisis data, yakni menganalisis data primer dengan bantuan data sekunder untuk memperoleh hasil sintesis data secara sistematis-kritis-reflektif. Selanjutnya Interpretasi data, yakni memberikan pemaknaan dan evaluasi kritis untuk memperoleh suatu pandangan yang berimbang, objektif dan mendalam tentang nilai-nilai kearifan lokal. Penulisan hasil analisis dan interpretasi, yakni menuliskan kembali hasil analisis dan interpretasi data secara teratur, sistematik-reflektif, dan proporsional.

\section{Hasil dan Pembahasan}

\section{a. Sejarah dan Nilai Toleransi di Desa Balun (Desa Pancasila)}

Berawal dari tragedi G30S PKI atau Gerakan 30 September Partai Komunis Indonesia, Desa Balun berlumuran darah dikarenakan pembantaian yang terjadi. Bathi, anak daerah yang bertugas menjadi pasukan militer di daerah Papua pun pulang ingin menyelesaikan masalah yang terjadi di desa asal Bathi tersebut. Tahun 1966 - 1997 Bathi menyelesaikan konflik tersebut dan mendapat julukan Mbah Bathi.

Tidak hanya mendapatkan julukan, Bathi juga diangkat menjadi kepala desa di Desa Balun. Tak berselang lama, Bathi menemukan selebaran dan sisa-sisa kitab perjanjian lama dan mencari info sumber dimana kitab-kitab itu seharusnya berada.singkat cerita, geraja yang menyimpan kitab-kitab 
tersebut berada di sebelah bengkel armada bus Widji. Bathi pun masuk Kristen dan menyatakan kepada seluruh warganya untuk bebas memilih memeluk agama yang diinginkan.

Dalam masa pemerintahan Mbah Bathi, agama Kristen mendapatkan banyak pengikut dan tidak banyak bergejolak dengan pemeluk agama lain, terlebih Kristen saat itu juga tidak melakukan penyebaran agama atau kristenisasi (Gemiharto, 2017). Proses penemuan jati diri agama akhirnya juga ditemukan oleh penganut Hindu yang sebelumnya merupakan penganut agama kepercayaan (Ramadhan, 2018). Kehadiran Tahardono Sasmito sebagai tokoh sesepuh Hindu juga tidak mendapatkan pergejolakan. Karena Desa Plosowayuh yang didominasi masyarakat beragama Hindu berdekatan dengan Desa Balun, secara mudah pula penyebaran agama Hindu di Desa Balun berkembang (Hemiharto, 2017).

\section{b. Kearifan Lokal di Desa Balun (Desa Pancasila)}

Penelitian tentang kearifan lokal merupakan penelitian yang menarik karena luar biasanya kearifan lokal yang ada di dalam budaya Indonesia. Salah satu contoh penelitian tentang kearifan lokal adalah penelitian tentang tradisi panai dalam perspektif filsafat nilai yang menyimpulkan ada banyak nilai seperti nilai kehidupan, nilai spiritual, nilai kerohanian (Alfariz, 2020).

Kearifan lokal merupakan pandangan hidup dan ilmu pengetahuan serta berbagai strategi kehidupan yang berwujud aktivitas yang dilakukan masyarakat lokal dam menjawab permasalahan dan pemenuhan kebutuhan yang menurut Koentjaraningrat dikategorikan menjadi tiga yakni gagasan atau ide, aktivitas sosial, dan artefak atau benda (Fajarini, 2014).

1) Gagasan

Slogan Desa Balun yakni Bedo raginyo, sing penting rukun yang memiliki arti walau berbedabeda namun tetap hidup rukun dan saling mengasihi (Ismail, 2019). Slogan tersebut selaras dengan Bhinneka Tunggal lka yang berarti berbeda-beda tetap satu jua. Syarat akan nilai kebersamaan dan tenggang rasa tergambar dalam slogan tersebut. Desa Balun mendapat julukan sebagai desa Pancasilabukan hanya karena slogan yang dimiliki saja, tetapi juga menyangkut tentang perilaku keseharian masyarakat di dalamnya. Toleransi merupakan nilai instrumental yang dipilih oleh Desa Balun untuk melangsungkan kehidupan berdampingan dengan keragaman budaya yang dimiliki.

2) Aktivitas sosial

Aktivitas sosial masyarakat berkaitan dengan bentuk sosialisasi masyarakat per individu dengan masyarakat lainnya. Dalam kehidupan masyarakat Balun, nilai-nilai agama yang dijalankan diminimalisir sebisa mungkin tidak mendapatkan pergesekan dengan pemeluk agama lainnya. Hal tersebut tertuang dalam setiap sikap masyarakat akan penghormatan dengan pemeluk agama lain yang dipandang merupakan saudara sendiri. Masyarakat Balun lebih mempertimbangkan nilai kemanusiaan dan menganggap beragama merupakan hak individu yang harus dihormati dan berkedudukan sama, sehingga dalam hal perpolitikan, tingkatan kekuasaan di dalam bermasyarakat, pemeluk agama apapun memiliki hak, selama ia adalah manusia.

Lembaga Swadaya Desa Balun memiliki kebebasan memilih ketua tidak mempertimbangkan agama yang dianut. Oleh karena itu, tidak hanya dalam perpolitikan, nilai-nilai tersebut juga tercermin dalam pelestarian budaya misalnya ogoh-ogoh yang merupakan budaya pemeluk agama Hindu juga dirayakan dan dibantu oleh pemuda muslim dan kristiani. Hal tersebut juga tercermin dalam berbagai acara di dalam masyarakat termasuk perayaan hari Kemerdekaan Nasional.

3) Artefak atau Benda-benda

Makam Mbah Alun yang dipercaya mampu membawa berkah di Desa Balun dan memiliki daya tarik tersendiri dalam aspek wisata religi (Ismail, 2019). Makam Mbah Alun merupakan makam dari seorang Raja Blambangan yakni Bedande Sakte Bhreau Arih yang bergelar Raja Tawang Alun I. Persembunyian Mbah Alun di Desa Balun dikarenakan serangan dari Belanda dan Mataram yang menghancurkan Kerajaan Blambangan (Gemiharto, 2017).

Gereja ada di sebelah timur, masjid berada di tengah, dan pura berada di barat (Ramadhan, 2018) merupakan salah satu keunikan yang tercermin di Desa Balun. Ketiga tempat peribadatan tersebut syarat akan nilai-nilai toleransi beragama yang menggambarkan bahwa masyarakat Balun saling hidup berdampingan saling menjaga dan menghormati satu sama lain.

\section{c. Sistem Religi di Desa Balun (Desa Pancasila)}

Koentjaraningrat (1987) dalam Pratiwi (2017) menyatakan bahwa ada tiga golongan teori-teori akan azaz religi yakni teori-teori yang dalam pendekatannya berorientasi pada keyakinan dalam religi, teori-teori yang dalam pendekatannya berorientasi pada sikap manusia terhadap alam gaib atau hal yang gaib, dan teori-teori yang dalam pendekatannya berorientasi pada upacara religi.

1) Keyakinan religi 
Sesuai dengan monografi Kantor Desa Balun menjelaskan bahwa 3.149 jiwa masyarakat Balun yang bergama Islam, 840 jiwa merupakan Kristen Protestan, 414 jiwa adalah penganut Hindu Darma, dan 2 jiwa menganut Sapta Darma. Dapat dilihat bahwa masyarakat di Desa Balun didominasi oleh tiga agama yakni Islam, Kristen, dan Hindu. Oleh karena itu, mereka dengan sukarela membangun peribadatan sesuai agama mereka masing-masing secara swadaya. Khusus untuk pembangunan pura yang merupakan representasi pura kabupaten, mendapatkan dana dari pemerintah daerah hingga provinsi (Priyowidodo, 2020: 46).

2) Sikap manusia terhadap alam gaib

Konsepsi manusia akan dunia ghaib dan spiritual yang mengelilinginya merupakan sistem keyakinan. Dengan adanya ketiga agama yang ada di Desa Balun, maka dapat ditarik kesimpulan bahwa semua masyarakat setempat mempercayai Tuhan. Budaya yang berkembang pun untuk memberikan peringatan tujuh hari pasca meninggal secara berturut-turut merupakan sebuah bukti bahwa masyarakat juga masih mempercayai bahwa ketika seseorang meninggal, maka rohnya masih ada di sekitar rumah sampai tujuh hari setelah kepergiannya (Santoso, 2017).

Tradisi turun balun merupakan salah satu bagian dari upacara religi yang memiliki area penting di aspek sikap manusia terhadap alam gaib karena masyarakat Balun percaya bahwa jika melewatkan tradisi turun balun, maka akan terjadi mala petaka dalam perayaan hajat atau bahkan terserang penyakit hingga perceraian. Seluruh keturunan Mbah Alun akan menyempatkan melakukan tradisi tersebut dan dapat dipastikan tidak hanya Islam, tetapi juga dijalankan oleh umat Kristen dan Hindu selama pemeluk-pemeluk agama tersebut masih merupakan keturunan dari Mbah Alun (Khoiroh, 2017).

\section{3) Upacara religi}

Prosesi tahlilan diikuti pula oleh pemeluk agama selain Islam. Tahlilan berlangsung di dalam rumah dengan posisi muslim di dalam dan non muslim di teras rumah. Hal tersebut sejalan dengan pembacaan doa yang dilakukan sesuai dengan agama masing-masing warga yang hadir dalam tradisi tahlilan tersebut (Ramadhan, 2018). Terkait dengan urusan hidangan, maka hidangan yang dimasak dalam suatu acara merupakan hidangan yang tidak dilarang oleh ketiga agama tersebut, dimana Islam dilarang memakan babi dan Hindu dilarang mengonsumsi sapi. Serta untuk menghindari kesalah pahaman, maka pihak yang menyembelih adalah pemuka agama Islam, karena memiliki kaidah-kaidah tersendiri yang dapat diterima oleh agama yang lain (Fuad, 2016).

Tradisi ogoh-ogoh disemarakkan pula oleh para pemuda Kristen dan Muslim, walaupun tradisi terebut dimiliki oleh pemeluk agama Hindu. Tidak hanya menyemarakkan, tetapi para pemuda bergotong royong untuk membuat, menghias, dan mengangkat berkeliling ogoh-ogoh yang dibuat untuk selanjutnya dibakar di lapangan secara bersama-sama tanpa perhitungan akan agama. Para pemuda Kristen juga tak masalah menyumbangkan dana untuk keberlangsungan tradisi ogoh-ogoh (Ramadhan, 2018).

Masyarakat Desa Balun menaati aturan pemerintah untuk tidak menikah beda agama. Oleh karena itu, salah satu calon mempelai harus berpindah keyakinan agar memiliki keyakinan yang sama antara keduanya. Namun, hal tersebut tidak menjadi konflik tersendiri di masyarakat karena agama merupakan hak setiap orang dan wajib dihormati.

Selanjutnya, jika kedua calon sudah ingin ke tahap selanjutnya yakni melangsungkan prosesi akad nikah, maka harus melakukan tradisi turun balun. Tradisi turun balun wajib dilakukan oleh setiap keturunan Mbah Alun setiap akan menikah, atau pun memiliki hajad lain seperti sunat, merantau ke daerah lain, dan menepati nazar. Turun balun diawali dengan nyadran yakni ziarah ke makam Mbah Alun yang dilakukan oleh calon mempelai serta keluarga, dalam hal ini dapat diwakilkan, tetapi harus membawa pakaian yang bersangkutan sebagai bukti telah melangsungkan turun balun dan di pimpin oleh pemuka agama. Kedua, petik bunga adalah rangkaian kedua dari turun balun. Si pemilik hajat harus memetik bunga yang ada di pemakamn Mbah Alun. Ketiga, pemilik hajat memberikan seserahan sesuai dengan kemampuan dan nazar si pemilik hajat kepada pemuka agama untuk dibagi kepada masyarakat Desa Balun serta si pemilik hajat dengan tujuan mendapat keberkahan dari tradisi tersebut bersama-sama (Khoiroh, 2017).

Perhitungan jawa tetap digunakan untuk menentukan hari-hari sakral, termasuk dalam menanam padi, membangun rumah, bahkan untuk pernikahan. Weton atau hari kelahiran juga masih membudaya di masyarakat Desa Balun. Oleh karena itu, walaupun berkembang dualisme anatara jawa dan agama, masayrakat seempat lebih memilih untuk mengikuti adat jawa ( Fuad, 2016).

\section{d. Nilai Toleransi}


Toleransi merupakan sikap saling menghargai, sehingga toleransi beragama adalah sikap saling menghargai antar keyakinan agama yang berbeda (Mutiara, 2016). Adapun prinsip-prinsip toleransi untuk mencapai ketenangan, ketentraman, dan keharmonisan antar umat bermasyarakat yakni kebebasan memilih agama, rasa persaudaraan dengan sesama, dan menerima perbedaan (Mustaqim, 2019).

Said Agil Husin Al-munawar dalam Mustaqim (2019) menyatakan ada beberapa pedoman bertoleransi yakni kesaksian yang jujur dan saling menghormati, prinsip kebebasan beragama, prinsip penerimaan, dan berpikir positif serta percaya (Mustaqim, 2019). Prinsip-prinsip tersebut menurut peneliti telah ada di dalam kehidupan masyarakat Balun.

Nilai toleransi menjadi nilai instrumental yang dimiliki oleh masyarakat di Desa Balun. Nilai toleransi dipilih oleh para pemuka agama sebagai landasan berperilaku karena memiliki martabat yang tinggi dan tidak semua orang bisa untuk mengamalkannya. Untuk mewujudkan hal tersebut, para pemuka agama memberikan contoh dan menjadi tauladan bagi masyarakat. Setiap acara entah berkaitan acara yang diinisiasi oleh tiap keluarga atau pun memang acara keagaamaan serta kerukunan warga, maka peran tokoh agama besar untuk menjadi contoh serta memberikan tuntunan agar menjunjung tinggi nilai toleransi sebagai bagian dari upaya menjadi makhluk beragama (Pinandita, 2020). Tak heran jika agama tidak menjadi masalah dalam mempertimbangkan pemimpin, hubungan sosial, serta pergaulan antar tetangga (Fuad, 2016).

Perayaan Proklamasi Kemerdekaan 17 Agustus di Desa Balun diinisiasi oleh kepala desa dan dirayakan oleh seluruh masyarakat Desa Balun. Tidak hanya donor darah masal, tetapi juga ada pentas seni yang menampilkan ciri khas dari Desa Balun yakni hidupnya ketiga agama tersebut. Muslim menampilkan qasidah, kristiani menampilkan band dan paduan suara, dan pemeluk agama hindu menampikan permainan gamelan serta tari Bali (Gemiharto, 2017).

Toleransi juga memiliki nilai sosial dan komitmen moral bagi masyarakat Desa Balun. Toleransi merupakan pengikat antar agama di dalam desa tersebut. Toleransi juga telah menjadi sikap alamiah di masyarakat yang termanivestasi dalam keseharian dan konstruksi sosial di masyarakat (Ulum, 2019). Tidak hanya dalam tradisi ogoh-ogoh serta prosesi tahlilan. Nilai toleransi juga berlangsung dalam beberapa aktivitas masyarakat yang syarat akan sikap menghargai satu sama lain yakni saat hari raya nyepi, warga muslim enggan untuk menyalakan lampu masjid sehingga nampak dari pura yang berdekatan dekat lokasi masjid. Warga non-Hindu keseluruhan juga sungkan untuk melakukan aktivitas yang mengganggu peribadatan hari raya nyepi seperti merenovasi rumah atau pun melakukan aktivitas yang mengundang kebisingan. Umat muslim juga sepakat untuk tidak menggunakan pengeras suara di luar masjid saat dilaksanakan solat jumat, cukup menggunakan pengeras suara di dalam masjid saja (Ramadhan, 2018).

Dalam suasana hajatan, masyarakat pemeluk non muslim sudah terbiasa untuk menggunakan kopiah dan kerudung sebagai rasa hormat terhadap hajatan itu sendiri. Dalam dua hari acara hajatan, biasanya di hari pertama dihadiri oleh keluarga, perangkat desa, serta tokoh agama sesuai dengan agama yang memiliki hajat. Pada hari kedua, ketiga penganut agama di Desa Balun datang bersama-sama. Hal yang lumrah pula di dalam satu keluarga memiliki agama yang bervariasi, sehingga terbentuk kewajaran apabila ada suatu acara atau pun ditimpa duka, masyarakat berhuyung-huyung membantu mulai dari prosesi penguburan hingga empat puluh hari pembacaan doa (Gemiharto, 2017).

\section{Simpulan dan Saran}

Slogan Desa Balun yakni Bedo raginyo, sing penting rukun yang memiliki arti walau berbeda-beda namun tetap hidup rukun. Aktivitas sosial masyarakat berkaitan dengan bentuk sosialisasi masyarakat per individu dengan masyarakat lainnya. Nilai-nilai agama yang dijalankan diminimalisir sebisa mungkin tidak mendapatkan pergesekan dengan pemeluk agama lainnya.hidup berdampingan saling menjaga dan menghormati satu sama lain. Nilai toleransi yang kuat di Desa Balun menjadikan Balun layak disebut sebagai Desa Pancasila, Desa yang menjunjung tinggi nilai-nilai religiusitas, desa yang menjunjung tinggi nilai-nilai Pancasila.

\section{Daftar Pustaka}

Alam, Masnur dkk. 2018. Penerapan Pendidikan Islam Anti-Radikal. Lentera Pendidikan, Vol. 21 No.2 Desember 2018.

Alfariz, Fitri. 2020. Tradisi Panai dalam Perspektif Filsafat Nilai. Jurnal Filsafat Indonesia, Volume 2, pp 35-39.

Alhairi. 2017. Pendidikan Anti Radikalisme: Ikhtiar Memangkas Gerakan Radikal. Jurnal Tarbawi Vo.14. No.2 Juli- Desember 2017. 
Ayatrohaedi, 1986. Kepribadian Budaya Bangsa (Local Genius), Jakarta: Pustaka Jaya.

Fajarini, Ulfah. 2014. Peranan Kearifan Lokal dalam Pendidikan Karakter. Jurnal Sosio Didaktiva: Vol. 1 No.2 Desember 2014.

Fuad, Ah. Zakki. 2016. Peace Building Berbasis Kearifan Lokal pada Masyarakat Plural.Ibda' Jurnal Kebudayaan IslamVol. 14, No. 1 Januari - Juni 2016.

Gemiharto, Ilham; Sukaesih. 2017. Komunikasi Lintas Budaya Masyarakat Multikultural di Desa Balun Kecamatan Turi Kabupaten Lamongan. Prosiding Konferensi Nasional Komunikasi, Vo. 01, No. 01, 2017.

Ismail, dkk. 2019. Desain Persatuan dan Kesatuan sebagai Ikon Desa Wisata Religi di Desa Balun Kecamatan Turi Kabupaten Lamongan. Jurnal Governance: Jurnal Kebijakan dan Manajemen Publik Bo. 9 No. 1 April 2019.

Khoiroh, Mustahbarotul. 2017. Tradisi Pernikahan Turun Balun: Studi Interaksi Tradisi Lokal dan Islam di Desa Balun Kecamatan Turi Kabupaten Lamongan. Skripsi Universitas Islam Negeri Maulana Malik Ibrahim Malang.

Maarif, Nurcholis. 2020. 4 Desa di Blitar Sabet Penghargaan Soal Nilai Pancasila. Detiknews https://news.detik.com/berita/d-5244327/4-desa-di-blitar-sabet-penghargaan-soal-nilaipancasila diakses pada 18 November 2020 pukul 19.00 WIB.

Masrizal. 2020. Salut! Pemuda Ketambe Sulap Hutan jadi Desa Wisata Pancasila Hingga Diresmikan Ketua MPR RI.aceh.tribunnes.com https://aceh.tribunnews.com/2020/10/30/salut-pemudaketambe-sulap-hutan-jadi-desa-wisata-pancasila-hingga-diresmikan-oleh-ketua-mprri?page=1 diakses pada 18 November 2020 pukul 20.01 WIB.

Masrukhi, Margi Wahono. 2019. Model Ikhtiar Pembudayaan Nilai-nilai Pancasila di Kalangan Masyarakat Desa. Bhinneka Tunggal Ika: Kajian Teori dan Praktis PKn Vol. 6, No.2 November 2019.

Medcom.id. 2020. Belajar Persatuan di Kampung Pancasila. Medcom.id https://www.medcom.id/nasional/daerah/Wb70gr6k-belajar-persatuan-di-kampung-pancasila diakses pada 18 November 2020 pukul 2016 WIB.

Mustaqim, Saeful. 2019. Implementasi Nilai Toleransi dalam Kehidupan Bermasyarakat antar Umat Beragama di Desa Gondoriyo Kecamatan Bergas Kabupaten Semarang. Skripsi Fakultas IImu Sosial Universitas Negeri Semarang.

Mutiara, Khilidia Efining. Menanamkan Toleransi Multi Agama sebagai Payung Anti Radikalisme (Studi Kasus Komunitas Lintas Agama dan Kepercayaan di Pantura Tali Akrab). Fikrah: Jurnal IImu Aqidah dan Studi Keagamaan Vo. 4 No. 2, 2016.

Pinandita, Yolanda, dkk. 2020. Komunikasi Tokoh Agama dalam Menepis SARA secara Agama di Desa Balun Pancasila Kabupaten Lamongan. Skripsi Universitas 17 Agustus 1945 Suarabayahttp://repository.untag-sby.ac.id/3478/diakses pada 17 November 2020 pukul 20.13 WIB.

Pratiwi, Citra Ayu. 2017. Horai: Telaah Konsep Religi Koentjaraningrat. Jurnal Japology, Vol. 5 No. 2 Maret -Agustus 2017.

Priyowidodo, Gatut. 2020. Etnografi Komunikasi: Testimoni Empiris Spirit Keragaman dan Komunitas Akar Rumput. Depok: PT. Rajagrafindo.

Ramadhan, As'ad Alno, dkk. 2018. Kehidupan Minoritas Beragama Masyarakat Desa Balun Lamongan dalam Konsep Multikulturalisme Joseph Raz. https://www.researchgate.net/publication/327132021_Kehidupan_Minoritas_Beragama_Masy arakat_Desa_Balun_Lamongan_Dalam_Konsep_Multikulturalisme_Joseph_Razdiakses pada 17 November 2020 pukul 19.18 WIB.

Santoso, Yohanes Candra Dwi. 2017. Kajian Sosio-Teologis tentang Peringatan Leluhur dan Orang Mati di Jemaat GKJW Wilayah Balun. Tugas Akhir Fakultas Teologi Universitas Kristen Satya Wacana Salatiga.

Sudjarwo, Eko. 2019. Desa Pancasila di Lamongan Diresmikan jadi Destinasi Wisata Religi. https://news.detik.com/berita-jawa-timur/d-4527493/desa-pancasila-di-lamongan-diresmikanjadi-destinasi-wisata-religi diakses pada 18 November 2020 pukul 20.26 WIB.

Surabaya.tribunnews.com. 2019. Balun, Desa Pancasila dan Desa Pariwisata Religi Terlengkap di Kabupaten Lamongan. https://surabaya.tribunnews.com/2019/11/14/balun-desa-pancasiladan-desa-pariwisata-religi-terlengkap-di-kabupaten-lamongandiakses pada 18 NOvember 2020 pukul 20.20 WIB. 